В.М. Петров, А.Ф. Кудрявцев, І.О. Кашаєв

Харківський національний університет Повітряних Сил ім. І. Кожедуба, Харків

\title{
МЕТОДИЧНИЙ ПІДХІД ДО РІШЕННЯ ЗАДАЧІ ПРИЦІЛЮВАННЯ ДЛЯ СКИДАННЯ ПОВІЛЬНО ПАДАЮЧИХ ВАНТАЖІВ 3 ТРАНСПОРТНИХ БЕЗПІЛОТНИХ ЛІТАЛЬНИХ АПАРАТІВ
}

У статті з використанням балістики повільно падаючих тіл, теорії і практики парашутного десантування транспортними пілотованими літальними апаратами розглядається методичний підхід до рімення задачі прицілювання для автоматизованого скидання повільно падаючих вантажів з перспективних транспортних безпілотних літальних апаратів. Під повільно падаючими вантажами розуміються бойова техніка, боєприпаси, продовольство та інші військові вантажі, щуо доставляються (скидаються) військам парашутним способом. Сутність рішення задачі прицілювання полягає у виведенні транспортного безпілотного літального апарату в розрахункову точку, при скиданні з якої забезпечується влучення повільно падаючого вантажу в заданий майданчик. У методичному підході, щуо розглядається, точка скидання вантажу розраховується з врахуванням фактичних параметрів польоту транспортного безпілотного літального апарату, балістичних характеристик вантажу, напряму і ивидкості середнього вітру, метод визначення яких пропонується.

Ключові слова: парашутний пристрій, повільно падаючий вантаж, параметр скидання, точка падіння вантажу, балістичні характеристики вантажу.

\section{Вступ}

Постановка проблеми. Багатофункціональність застосування безпілотних літальних апаратів (БпЛА) у збройних силах провідних країн світу вже стала реальністю. Останнім часом БпЛА залучаються також для виконання логістичних завдань, перевезення вантажів різними способами. У зв'язку з відсутністю ризику втрат дорогих пілотованих літальних апаратів і льотного складу актуальним для матеріально-технічного забезпечення (МТ3) частин і підрозділів різнорідних угруповань, що знаходяться у відриві від основних сил, стає використання транспортних БпЛА. Більшість вантажів для МТЗ таких угруповань можуть доставлятись лише парашутним способом - шляхом скидання так званих повільно падаючих вантажів (ППВ) [1-12]. Для забезпечення точного скидання ППВ у задану точку необхідно вирішувати задачу прицілювання, яка у загальному вигляді полягає у виведенні БПЛА в розрахункову точку, при скиданні з якої забезпечується влучення ППВ на заданий майданчик. Точка скидання вантажу повинна розраховуватися з урахуванням фактичних параметрів польоту, які змінюються: напряму заходу БпЛА, висоти і швидкості скидання, напряму і швидкості вітру, балістичних характеристик вантажу [10].

Мета статті. На основі використання балістики повільно падаючих тіл, теорії та практики парашутного десантування транспортними пілотованими літальними апаратами розробити методичний підхід до рішення задачі прицілювання при скиданні ППВ 3 перспективних транспортних БпЛА.

\section{Виклад основного матеріалу}

Рішення задачі прицілювання для скидання ППВ можливо здійснювати 3 використанням горизонтованої необертальної системи координат О ๆ $\zeta$ та горизонтованої обертальної шляхової системи координат OXZY [13-15] (рис. 1).

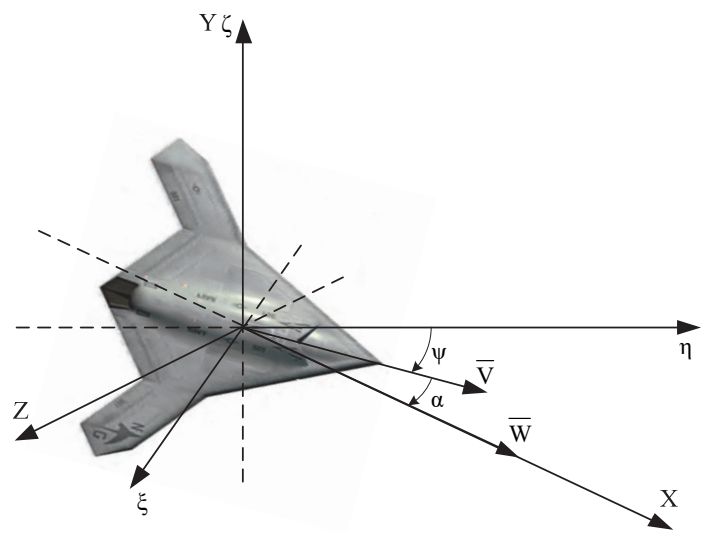

Рис. 1. Прямокутні системи координат, що використовуються при рішенні задачі прицілювання для скидання ППВ Джерело: розроблено авторами.

У прямокутній горизонтованій необертальній системі координат початок знаходиться на БПЛА, вісь $\eta \in$ початком ортодромічного курсу $(\psi)$ в інерціальній системі і спрямована по дотичній до орто- 
дромічної паралелі, вісь $\xi$ перпендикулярна осі $\eta$ в площині горизонту і спрямована по ортодромічному меридіану, вісь $\zeta$ спрямована по місцевій вертикалі вгору. Ця система координат при польоті БпЛА зберігає незмінну орієнтацію осей відносно площини меридіану точки виставки інерціальної системи БпЛА. У прямокутній обертальній шляховій системі координат початок сполучений з центром мас БпЛА, вісь OX співпадає 3 напрямом вектору шляхової швидкості БпЛА ( $\bar{W}$ ), вісь OZ перпендикулярна до осі OX і спрямована вправо, вісь OY спрямована перпендикулярно вгору. На рис. 1 позначено: $\psi-$ ортодромічний курс, $\alpha-$ кут зносу БпЛА.

Положення точки скидання ППВ (потрібні координати) розраховується у бортовій цифровій обчислювальній системі (БЦОС) БПЛА відносно заданої точки приземлення вантажів (ТПВ) [14-16]. Для розрахунку ії положення необхідно визначити елементи траєкторії зниження ППВ. Основними елементами траєкторії ППВ є [16]:

- середня швидкість зниження - $V_{\text {зн }}$;

- сумарний (загальний) час зниження - $T_{3 H_{\Sigma}}$;

- штильове віднесення ППВ - $A_{0}$;

- знесення ППВ під впливом вітру $-Z$.

Середня швидкість зниження ППВ приводиться у спеціальних таблицях або розраховується за формулою:

$$
V_{\text {зн.сp }}=\sqrt{\frac{2 G}{S \rho_{c p} C}},
$$

де $G$ - вага ППВ (разом з парашутною системою), кг;

$S$ - площа купола (куполів) парашутної системи, $\mu^{2}$;

$\rho_{c p}$ - масова щільність повітря у середній ділянці траєкторії зниження ППВ (в одиницях виміру МКГСС, кг $\left.\mathrm{c}^{2} / \mathcal{M}^{4}\right)$;

$C$ - коефіцієнт лобового опору парашутної системи (балістичний коефіцієнт), який залежить від типу парашутної системи та умов скидання.

Масова щільність повітря у середній ділянці траєкторії зниження ППВ визначається як:

$$
\rho_{c p}=\frac{\rho_{0}+\rho_{H}}{2},
$$

де $\rho_{0}, \rho_{\mu}$ - масова щільність повітря у землі (на нульової висоті) та висоті початку зниження ППВ відповідно.

У випадку, коли невідомі які-небудь величини, що входять до виразу (1) для визначення середньої швидкості зниження ППВ, але відома швидкість його приземлення (з тактико-технічних характерис- тик), то швидкість зниження ППВ розраховується за виразом:

$$
V_{\text {зн.ср }}=V_{0} \sqrt{\frac{\rho_{0}}{\rho_{H}}},
$$

де $V_{0}$ - вертикальна швидкість зниження ППВ у поверхні землі (швидкість приземлення).

При розрахунках для визначення прицільних даних для скидання ППВ значення середніх швидкостей зниження на етапах зниження на стабілізуючих і основних куполах вибирається із спеціальних таблиць, які наведені у відповідних інструкціях та інших документах.

Найбільш часто для визначення балістичних характеристик ППВ середня швидкість зниження розраховується для усереднених умов.

Сумарний час зниження ППВ визначається за формулою:

$$
T_{3 H_{\Sigma}}=\frac{H_{c}-h_{c m}^{*}}{V_{\text {зн.сp }}}+T_{1}=\frac{h_{\text {oсн }}^{*}}{V_{\text {зн.сp }}}+T_{1},
$$

де $H_{c}$ - істинна висота скидання ППВ, $м$;

$h_{c m}^{*}$ - висота зниження ППВ на стабілізуючому парашуті (висота від моменту розкриття стабілізуючого парашута до моменту початку розкриття основних парашутів);

$T_{1}$ - час зниження ППВ на стабілізуючому парашуті.

Значення $h_{c m}^{*},\left(h_{o c н}^{*}\right), V_{\text {зн.осн }}, T_{1}$ залежать від типу парашутів (парашутної системи), що застосовуються при скиданні, ваги вантажу і щільності повітря в районі скидання, отримуються експериментальним шляхом i наводяться в Інструкціях по льотної експлуатації (Інструкціях по бойовому застосуванню) пілотуємих транспортних ЛА. При вирішенні практичних завдань можна використовувати такі значення:

- при скиданні вантажів на парашуті типу Д-1: $h_{c m}^{*}=150 \mathrm{м}, T_{1}=8 \mathrm{c}$;

- при скиданні вантажів на парашуті типу Д-5: $h_{c m}^{*}=100 \mathrm{M}, T_{1}=5 \mathrm{c}$;

- при скиданні на навчальних парашутах типу ПТП-2: $h_{c m}^{*}=0 \mathrm{M}, T_{1}=0 \mathrm{c}, V_{3 н}=5 \mathrm{M} / \mathrm{c}$;

- при скиданні штатного вантажу 3 парашутною системою типу ОКС-4: $h_{c m}^{*}=150 \mathrm{M}, T_{1}=8 \mathrm{c}$, $V_{3 н}=7 \mathrm{M} / \mathrm{c}$.

Штильове віднесення ППВ - шлях, що проходить ППВ у горизонтальній площині після відокремлення від БпЛА в умовах безвітря. Величина шти- 
льового віднесення залежить від балістичних характеристик ППВ $(C)$, висоти $\left(H_{c}\right)$ і швидкості БпЛА при скиданні $(V)$, маси вантажу і парашутної системи $(G)$, площі куполів $(S)$, часу вільного падіння $\left(t_{\text {b.nад. }}\right)$, часу зниження на стабілізуючому парашуті $\left(t_{c m}\right)$, часу наповнення основних куполів $\left(t_{\text {н.осн. }}\right)$, швидкості зниження ППВ $\left(V_{3 н}\right)$ та інших факторів:

$$
A_{0}=f\left(c, H_{c}, V, G, S, t_{\text {в.пад }}, t_{c m}, t_{\text {н.осн }}, V_{\text {зн }}\right) \text {. }
$$

Величини штильових віднесень різних ППВ визначаються дослідним шляхом і зводяться у відповідні таблиці, які наведені в Інструкціях по бойовому застосуванню (льотної експлуатаціі) пілотуємих транспортних ЛА. Приклад значень віднесення вантажів різної маси залежно від швидкості і висоти скидання показаний у табл. 1.

Таблиця 1

Віднесення вантажів різної маси (у метрах) залежно від швидкості і висоти скидання (при затримці розкриття парашута 5 с)

\begin{tabular}{|c|c|c|c|c|c|c|c|c|c|}
\hline \multirow{2}{*}{$\begin{array}{c}V \text { скидання, } \\
\text { км/год }\end{array}$} & \multicolumn{9}{|c|}{ Висота скидання, м } \\
\hline & 400 & 600 & 800 & 1000 & 1200 & 1600 & 2000 & 3000 & 4000 \\
\hline \multicolumn{10}{|c|}{ Маса вантажу 90 кг } \\
\hline 300 & 244 & 229 & 246 & 254 & 258 & 264 & 271 & 295 & 313 \\
\hline 330 & 233 & 238 & 256 & 264 & 268 & 274 & 282 & 309 & 329 \\
\hline 360 & 241 & 246 & 265 & 273 & 277 & 284 & 292 & 321 & 344 \\
\hline 390 & 249 & 254 & 273 & 281 & 285 & 292 & 300 & 331 & 357 \\
\hline 420 & 256 & 261 & 281 & 288 & 292 & 299 & 307 & 339 & 368 \\
\hline 450 & 263 & 268 & 288 & 295 & 299 & 306 & 312 & 345 & 377 \\
\hline \multicolumn{10}{|c|}{ Маса вантажу 120 кг } \\
\hline 300 & 267 & 273 & 306 & 316 & 324 & 332 & 340 & 365 & 394 \\
\hline 330 & 279 & 285 & 320 & 330 & 338 & 346 & 354 & 379 & 414 \\
\hline 360 & 289 & 296 & 332 & 342 & 350 & 358 & 368 & 393 & 432 \\
\hline 390 & 298 & 306 & 342 & 352 & 362 & 370 & 378 & 407 & 448 \\
\hline 420 & 306 & 315 & 350 & 361 & 372 & 380 & 388 & 420 & 462 \\
\hline 450 & 313 & 323 & 357 & 369 & 380 & 388 & 396 & 431 & 474 \\
\hline
\end{tabular}

Джерело: розроблено авторами.

Знесення ППВ $(Z)$ визначається відстанню між проекцією точки початку зниження ППВ і точкою його приземлення. Вітер, що впливає на ППВ, не впливає на відомі нам елементи траєкторії зниження ППВ: $V_{3 н}, T_{3 \mu_{\Sigma}}, A_{0}$, але має істотний вплив на траєкторію ППВ, оскільки з'являється новий елемент траєкторії зниження - вектор знесення вантажу $(\bar{Z})$.

Величина і напрям вектору знесення $(\bar{Z})$ визначається напрямом i швидкістю середнього вітру в прошарку висоти скидання і сумарним часом зниження ППВ.

Середнім вітром називають постійний за швидкістю і напрямом вітер, еквівалентний всім вітрам, що впливає на вантаж при зниженні його на парашуті.

Отже, величина знесення визначається за формулою:

$$
Z=U_{c p} T_{3 H \Sigma}
$$

де $\mathrm{U}_{\mathrm{cp}}$ - швидкість середнього вітру, м/с.
Напрям знесення визначається напрямом середнього вітру ( $\left.\delta_{c p}\right)$, який відлічується від північного напряму істинного меридіана до напряму, звідки він дме. Як правило, в практиці десантування середній вітер і знесення ППВ визначаються для всього прошарку повітря від земної поверхні до висоти скидання вантажу.

Визначення параметрів середнього вітру здійснюється різними способами і для виводу БпЛА у ТПС може вводитись автоматично. При польоті БпЛА до ТПС на малій або гранично малій висоті, а скидання - 3 більшої висоти (з середньої або великої) може застосовуватись спосіб визначення середнього вітру при наборі висоти (рис. 2).

На ділянці набору висоти (в районі ТПВ) через кожні (100-200) метрів (точки 1-5) по значенням параметрів польоту (висоти, істинної швидкості польоту $(V)$, кута зносу $(\alpha)$, шляхової швидкості польоту $(W)$ та шляховому куту польоту БпЛА ( $\beta$ ) визначаються напрям та швидкість вітру за кожним шаром. 


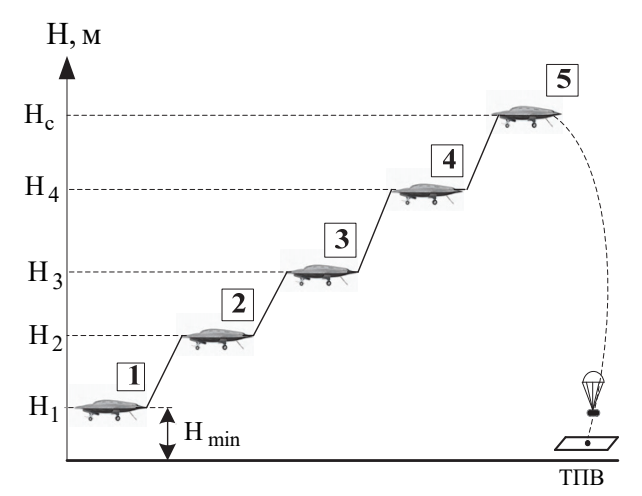

Рис. 2. Схема визначення параметрів середнього вітру при наборі висоти Джерело: розроблено авторами.

Розрахунок напряму вітру при наборі висоти (у точках 1-5) здійснюється з використанням параметрів відомого навігаційного трикутнику швидкостей [14] (рис. 3).

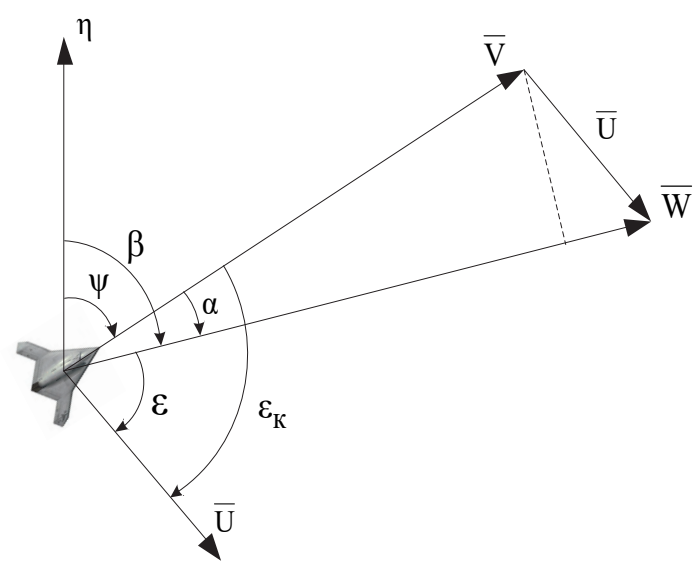

Рис. 3. Навігаційний трикутник швидкостей Джерело: розроблено авторами.

Для розрахунку напряму вітру в кожному шарі повітря використовується формула:

$$
\delta_{i}=\beta_{i}+\operatorname{arctg}\left(\frac{V_{i} \sin \alpha_{i}}{W_{i}-V_{i} \cos \alpha_{i}}\right),
$$

де $\delta_{i}-$ напрям вітру в $i$-му шарі $(i=1 \ldots n)$ при наборі висоти БПЛА для визначення середнього вітру;

$\beta_{i}$ - шляховий кут польоту БпЛА в $i$-му шарі;

$V_{i}$ - істинна швидкість польоту БпЛА в $i$-му шарі;

$\alpha_{i}$ - кут зносу БпЛА в $i$-му шарі;

$W_{i}$ - шляхова швидкість польоту БпЛА в $i$-му шарі.

При визначенні навігаційного напряму вітру $\left(\delta_{i}\right)$ може виникнути неоднозначність на $180^{\circ}$ (в залежності від того, співпадає він 3 напрямом польоту БпЛА (попутний напрям вітру) або не співпадає). Якщо напрям вітру попутний (при цьому шляхова швидкість польоту БпЛА більше істинної швидкості), то визначений напрям (7) є справжнім, якщо напрям вітру не $\epsilon$ попутним (при цьому шляхова швидкість польоту БпЛА менше істинної швидкості), то він змінюється на протилежний, тобто використовується наступне правило:

$$
\begin{aligned}
& \delta_{i}=\delta_{i}^{*} \rightarrow \text { npu } W>V, \\
& \delta_{i}=\delta_{i}^{*} \pm 180^{\circ} \rightarrow \text { npu } W<V .
\end{aligned}
$$

При цьому знак “+” при $\delta_{i}^{*} \leq 180^{\circ}$, знак “-”" при $\delta_{i}^{*}>180^{\circ}$, при появі $\delta_{i}^{*}$ зі знаком “_” додається 360 градусів.

Розрахунок швидкості вітру здійснюється за виразом:

$$
u_{i}=\left|\frac{V_{i} \sin \alpha_{i}}{\sin \left[\operatorname{arctg}\left(\frac{V_{i} \sin \alpha_{i}}{W_{i}-V_{i} \cos \alpha_{i}}\right)\right]}\right| .
$$

На рис. 3, крім вказаних параметрів, позначено: $\psi$ - курс польоту БпЛА;

$\varepsilon$ - кут вітру (кут між вектором шляхової швидкості та вектором вітру);

$\varepsilon_{\text {к }}-$ курсовий кут вітру (кут між вектором швидкості (повздовжньої віссю БПЛА) та вектором вітру).

Після визначення вітру у кожному шарі при наборі висоти, знаходиться середнє значення напряму та швидкості вітру за виразами:

$$
\begin{array}{r}
\delta_{c p}=\frac{\sum_{i=1}^{n} \delta_{i}}{n}, \\
u_{c p}=\frac{\sum_{i=1}^{n} u_{i}}{n} .
\end{array}
$$

Завдання прицілювання при скиданні ППВ в загальному вигляді полягає у наданні БпЛА такого положення у просторі відносно ТПВ, за якого траєкторія зниження ППВ, відокремленого від БПЛА, пройде через задану точку на рівні земної поверхні (ТПВ), тобто керуючи польотом БПЛА забезпечити такі початкові умови, за яких ППВ влучить в задану точку. Принцип рішення задачі прицілювання при скиданні ППВ показаний на рис. 4.

3 балістики ППВ [14] відомо, що положення ТПС відносно заданої точки приземлення (ТПВ) визначається вектором повного віднесення $\left(\bar{A}_{\Sigma}^{*}\right)$. 


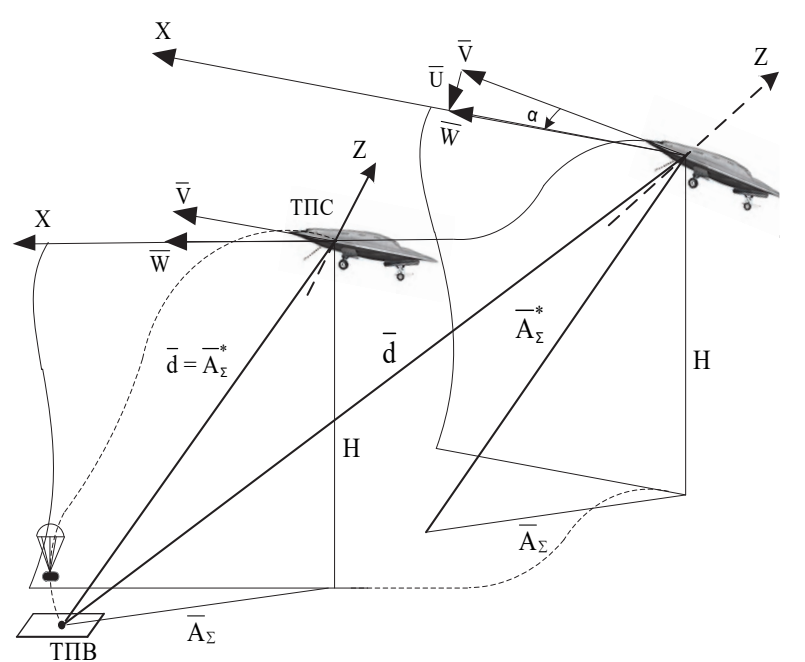

Рис. 4. Принцип рішення задачі прицілювання при скиданні ППВ

Джерело: розроблено авторами.

Вектор повного віднесення визначається:

$$
\bar{A}_{\Sigma}^{*}=H_{c}+\bar{S}_{3}+\bar{A}_{0}+\bar{Z},
$$

де $\bar{S}_{3}=\bar{W} t_{3}-$ довжина ділянки запізнювання початку скидання ППВ;

$\bar{A}_{0}$ - штильове віднесення ППВ;

$t_{3}$ - час запізнювання початку скидання ППВ;

$\bar{Z}=\bar{U}_{c p} T_{\text {зн }_{\Sigma}}-$ вектор знесення ППВ вітром за загальний час зниження $\left(T_{3 \mu_{\Sigma}}\right)$ у напряму середнього вітру $\left(\delta_{c p}\right)$.

Поточне положення БпЛА відносно точки приземлення визначається вектором дальності $\bar{d}$ (рис. 4). Момент виходу БпЛА у ТПС буде визначатись рівністю вектора $\bar{d}$ і вектора $\bar{A}_{\Sigma}^{*}\left(\bar{d}=\bar{A}_{\Sigma}^{*}\right)$.

Для реалізації процесу прицілювання використовуються не самі вектори, а їх проекції на осі координат. При цьому системи координат вибираються такими, що забезпечують зручність вирішення завдання прицілювання, достатню точність розрахунку всіх елементів прицільної схеми. Оскільки скидання ППВ здійснюється, як правило, серійно, то завдання прицілювання має при цьому свої особливості.

Якщо скидання вільно падаючих вантажів (бомбометання) може здійснюватись при заході на ціль 3 будь-якого напряму (крім вузьких площинних цілей), то скидання ППВ здійснюється, як правило, тільки із заданого напряму. Напрям заходу при цьому вибирається завжди паралельно довгій стороні майданчику падіння вантажів, що забезпечує приземлення серії ППВ на цьому майданчику і відповідає вимогам безпеки.
При заданої кількості вантажів $(n)$ та інтервалу ïx скидання $\left(t_{i}\right)$ з БпЛА потрібна довжина майданчику приземлення ППВ $\left(L_{n}\right)$ визначатиметься за формулою (рис. 5):

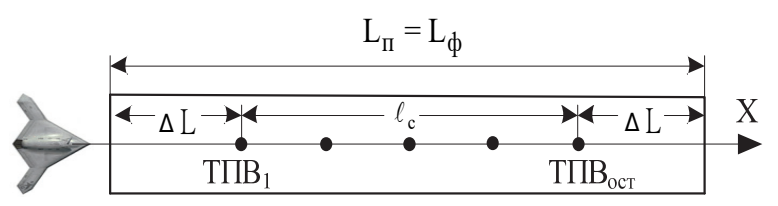

Рис. 5. Положення точок приземлення ППВ при їх серійному скиданні Джерело: розроблено авторами.

$$
L_{n}=\ell_{c}+2 \Delta L=W t_{i}(n-1)+2 \Delta L,
$$

де $L_{n}$ - потрібна довжина майданчику приземлення ППВ;

$\ell_{c}-$ довжина серії скидання ППВ;

$t_{i}$ - часовий інтервал скидання ППВ з БпЛА;

$n$ - кількість ППВ, що скидаються з БПЛА;

$\Delta L$ - безпечна відстань від початку та кінця майданчику приземлення до точки падіння першого $\left(\mathrm{TПB}_{1}\right)$ та останнього $\left(\mathrm{TПВ}_{\text {ост }}\right)$ вантажу.

Інтервал скидання вантажів з БПЛА береться різним залежно від типу БпЛА, типу вантажу і даних роботи десантного обладнання.

Для скидання ППВ у межах заданого майданчику його фактична довжина повинна бути не менше потрібної, тобто:

$$
L_{\phi} \geq L_{n}
$$

де $\mathrm{L}_{\phi}$ - фактична довжина майданчику приземлення вантажів.

У процесі виконання прицілювання визначається:

- положення ТПС відносно ТПВ, що характеризується координатами точки приземлення (майданчику приземлення);

- поточне положення БПЛА відносно ТПВ.

При прицілюванні поточні координати БпЛА (за відстанню і напрямом) порівнюються 3 потрібними координатами точки початку скидання. Прицільна схема при скиданні ППВ показана на рис. 6.

На першому етапі здійснюється вивід БпЛА на лінію заданого бойового шляху та виконання бічного наведення, для чого обчислюється параметр управління:

$$
q=Z-Z_{n},
$$

де $Z$ - поточна бічна координата БпЛА відносно ТПВ; 
$Z_{n}$ - потрібна бічна координата БпЛА відносно ТПВ.

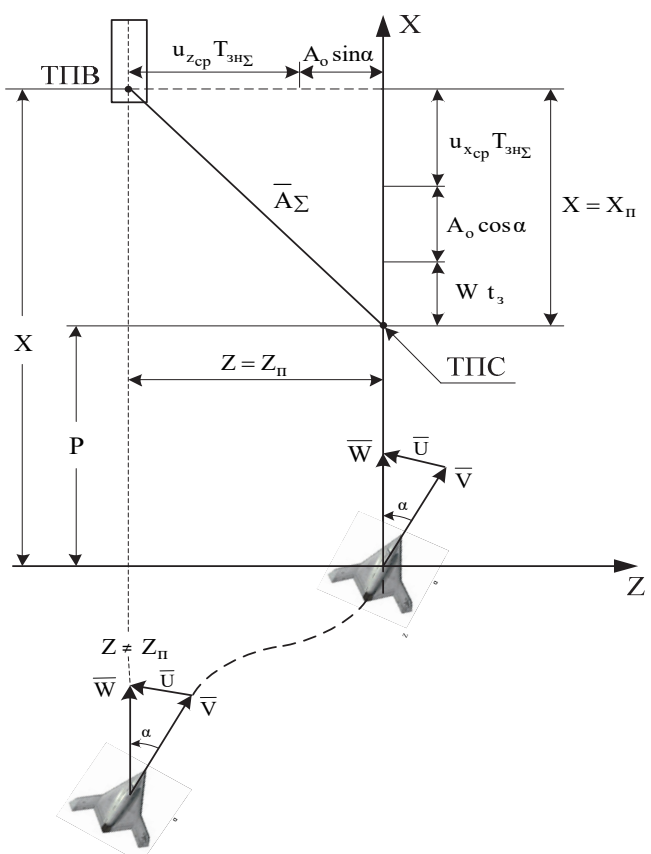

Рис. 6. Прицільна схема при скиданні ППВ Джерело: розроблено авторами.

На другому етапі виконується прицілювання за відстанню - визначення моменту початку скидання вантажу. Для цього визначається параметр скидання:

$$
P=X-X_{n},
$$

де $X$ - поточна подовжня координата БпЛА відносно ТПВ;

$X_{n}-$ потрібна подовжня координата точки початку скидання відносно ТПВ.

Завдання прицілювання буде вирішеним, якщо виконані бічне наведення і прицілювання за відстанню, тобто:

$$
\begin{aligned}
& Z=Z_{n}, \\
& X=X_{n} .
\end{aligned}
$$

Поточні координати БпЛА визначаються шляхом їх зчислення інерціальною системою з використанням наступних рівнянь (11-13):

$$
\begin{gathered}
\xi=\xi_{0}+\int_{0}^{t} W_{\xi} d t ; \\
\eta=\eta_{0}+\int_{0}^{t} W_{\eta} d t,
\end{gathered}
$$

де $\xi, \eta$ - поточні координати БпЛА у горизонтованої необертальної системі координат (рис. 1); $\xi_{0}, \eta_{0}$ - початкові координати БпЛА, звідки починається зчислення шляху інерціальною системою;

$W_{\xi}, W_{\eta}$ - швидкості зміни координат БпЛА.

Перерахунок поточних координат БпЛА з прямокутної необертальної системи координат в обертальну здійснюється по формулах:

$$
\begin{aligned}
& x=\eta \cos \psi+\xi \sin \psi ; \\
& z=\eta \sin \psi+\xi \cos \psi .
\end{aligned}
$$

Очевидно, що при цьому поточна координата:

$$
y=\zeta=H,
$$

де $H$ - висота польоту БпЛА.

Потрібні подовжня та бічна координати БпЛА у ТПС відносно ТПВ визначаються:

$$
\begin{aligned}
& X_{n}=W t_{3}+A_{o} \cos \alpha+u_{x_{c p}} T_{3 н \Sigma} ; \\
& Z_{n}=A_{o} \sin \alpha+u_{z_{c p}} T_{3 н \Sigma},
\end{aligned}
$$

де $u_{x_{c p}}, u_{z_{c p}}$ - подовжня та бічна складові середньої швидкості вітру.

Подовжня та бічна складові середньої швидкості вітру визначаються:

$$
\begin{aligned}
& u_{x_{c p}}=u_{c p} \cos \left(\delta_{c p}-\beta_{\sigma}\right)=u_{c p} \cos \left(\delta_{c p}-\psi_{\sigma}+\alpha\right) ; \\
& u_{z_{c p}}=u_{c p} \sin \left(\delta_{c p}-\beta_{\sigma}\right)=u_{c p} \sin \left(\delta_{c p}-\psi_{\sigma}+\alpha\right),
\end{aligned}
$$

де $\beta_{\sigma}$ - бойовий шляховий кут польоту БпЛА;

$\psi_{\sigma}-$ бойовий курс польоту БпЛА.

Точність рішення задачі прицілювання буде залежати від точності зчислення координат, можливості та точності їх корекції.

\section{Висновки}

Розроблено методичний підхід до розв'язання задачі прицілювання при доставці вантажів парашутним способом з транспортних БпЛА. Розв'язання задачі прицілювання зводиться до розрахунку потрібних подовжніх і бічних координат, визначення моменту скидання шляхом порівняння їх з поточними подовжніми і бічними координатами (відстанями) БпЛА до заданої точки падіння, що забезпечує влучення ППВ у задану точку. Положення точки падіння ППВ в просторі може задаватися координатами, вказуватися оператором на цифровій карті або позначатися безпосередньо на місцевості. При позначенні місця падіння ППВ поточні координати можуть визначатися за допомогою візирного пристрою, який може бути телевізійним (лазерним), радіолокаційним або інфрачервоним. 


\section{Список літератури}

1. Воронов В.В. Беспилотные авиасистемы для грузоперевозок: оценка разработок (часть 2) [Електронний ресурс] / В.В. Воронов. - Режим доступу: http://www.ato.ru/content/bespilotnye-aviasistemy-dlya-gruzoperevozok-ocenka razrabotokchast-2.

2. Reuters. US Marines extend K-MAX unmanned helicopter's use in Afghanistan. - 2013. - [Electronic resource]. Available at: https://www.reuters.com/article/lockheed-unmanned-helicopter-idUSL1N0C603420130317.

3. Mistake Slows K-46 Timetable. MINUSMA Takes Delivery of Tatas. K-Max Set to Pass ARES, AACUS. [Electronic resource]. - Available at: http://www.defenseindustrydaily.com/mistake-slows-k-46-timetable-minusma-takes-delivery-of-tatask-max-set-to-pass-ares-aacus-030593.

4. US Department of Defense. United States Department of Defense Fiscal Year 2011 - 2036. Unmanned Systems Integrated Roadmap [Electronic resource]. - Available at: https://fas.org/irp/program/collect/usroadmap2011.pdf.

5. Vacca A. Drones: military weapons, surveillance or mapping tools for environmental monitoring? The need for legal framework is required / A. Vacca, H. Onishi // Transportation Research Procedia. - 2017. - No. 25. - P. 51-62. https://doi.org/10.1016/j.trpro.2017.05.209.

6. Unmanned Systems Integrated Roadmap FY2013-2038. - Washington, D.C.:Department of Defense, 2013. [Electronic resource]. - Available at: https://archive.defense.gov/pubs/DOD-USRM-2013.pdf.

7. Franklin McDonald Jr. J. Critical Technologies. The United States Department of Defense Efforts to Shape Technology Development after the Cold War - A Discourse and Network Analysis [Electronic resource] / J. Franklin McDonald Jr. - Available at: https://vtechworks.lib.vt.edu/bitstream/handle/10919/56625/McDonald_JF_D_2014.pdf?isAllowed=y\&sequence $=1$.

8. Murray C. China's Military Unmanned Aerial Vehicle Industry. - June 13, 2013. [Electronic resource] / C. Murray, J. Cook, A. Feld. - Available at: https://www.uscc.gov/sites/default/files/Research/China\%27s\%20Military\%20UAV \%20Industry_14\%20June\%202013.pdf.

9. Алімпієв А.М. Тактика транспортної авіації. Ч. 1. Основи тактики транспортної авіації / А.М. Алімпієв, Ю.М. Корнусь, С.А. Калкаманов. - Х.: ХНУПС, 2017. - 268 с.

10. Алімпієв А.М. Тактика транспортної авіації. Ч. 2. Бойове застосування підрозділів транспортної авіації / А.М. Алімпієв, Ю.М. Корнусь, С.А. Калкаманов. - Х.: ХНУПС, 2017. - 116 с.

11. Основні тенденції створення та застосування груп безпілотних літальних апаратів / В.А. Лупандін, Г.В. Мегельбей, О.Й. Мацько, Т.Л. Куртсеітов, П.О. Міроненко // Наука і техніка Повітряних Сил Збройних Сил України. - 2019. - № 2(35). - C. 88-96. https://doi.org/10.30748/nitps.2019.35.11.

12. Шамко В.С. Розвиток форм і способів застосування Повітряних Сил Збройних Сил України в сучасних умовах ведення збройної боротьби / В.С. Шамко, О.М. Жарик, В.В. Коваль // Наука і техніка Повітряних Сил Збройних Сил України. - 2018. - № 2(31). - С. 9-15. https://doi.org/10.30748/nitps.2018.31.01. $-285 \mathrm{c}$

13. Прицельно-навигационные комплексы летательных аппаратов / Под ред. Ю.В. Косюка. - М.: Воениздат, 1982.

14. Романовский А.П. Применение геотехнических средств воздушной навигации / А.П. Романовский, Ю.А. Матвеев, Е.П. Ремянников. - М.: Воениздат, 1992. - 304 с.

15. Августов Л.И. Навигация летательных аппаратов в околоземном пространстве / Л.И. Августов, А.В. Бабиченко, [и др.] / Под ред. Г.И. Джангжава. - М.: Научтехиздат, 2015. - 592 с.

16. Корочкін О.А. Теорія парашутного десантування / О.А. Корочкін, А.П. Корнієнко. - Х.: ХНУПС, 2011. - 153 с.

Надійшла до редколегії 17.11.2020

Схвалена до друку 15.12.2020

\section{Відомості про авторів:}

\author{
Петров Василь Миколайович \\ кандидат військових наук \\ старший науковий співробітник \\ Харківського національного університету \\ Повітряних Сил ім. І. Кожедуба, \\ Харків, Україна \\ https://orcid.org/0000-0003-4324-7540
}

\section{Кудрявцев Андрій Федорович}

науковий співробітник

Харківського національного

університету Повітряних Сил ім. І. Кожедуба, Харків, Україна

https://orcid.org/0000-0002-0319-6681

\section{Кашасв Ігор Олександрович}

кандидат технічних наук доцент

старший науковий співробітник Харківського національного університету Повітряних Сил ім. І. Кожедуба,

Харків, Україна

https://orcid.org/0000-0002-8684-6271

\section{Information about the authors:}

Vasyl Petrov

Candidate of Military Sciences

Senior Research

of Ivan Kozhedub Kharkiv

National Air Force University,

Kharkiv, Ukraine

https://orcid.org/0000-0003-4324-7540

\author{
Andrii Kudriavtsev \\ Research Associate \\ of Ivan Kozhedub Kharkiv \\ National Air Force University, \\ Kharkiv, Ukraine \\ https://orcid.org/0000-0002-0319-6681
}

\section{Igor Kashaev}

Candidate of Technical Sciences Associate

Professor Lead Research

of Ivan Kozhedub Kharkiv

National Air Force University,

Kharkiv, Ukraine

https://orcid.org/0000-0002-8684-6271 


\title{
МЕТОДИЧЕСКИЙ ПОДХОД К РЕШЕНИЮ ЗАДАЧИ ПРИЦЕЛИВАНИЯ ДЛЯ СБРОСА МЕДЛЕННО ПАДАЮЩИХ ГРУЗОВ ИЗ ТРАНСПОРТНЫХ БЕСПИЛОТНЫХ ЛЕТАТЕЛЬНЫХ АППАРАТОВ
}

\author{
В.Н. Петров, А.Ф. Кудрявцев, І.О. Кашаєв
}

В статье с использованием баллистики медленно падающих тел, теории и практики парашютного десантирования транспортными пилотируемыми летательныли аппаратами рассматривается методический подход к решению задачи прицеливания для автоматизированного сброса медленно падаюших грузов с перспективных транспортных беспилотных летательных аппаратов. Под медленно падающими грузами понимаются боевая техника, боеприпасы, продовольствие и другие военные грузы, доставляемые (сбрасываемые) войскам парашютным способом. В общем виде задача прицеливания заключается в выведении транспортного беспилотного летательного аппарата в расчетную точку, при сбросе из которой обеспечивается попадание медленно падающего груза в заданную точку (площадку). В рассматриваемом методическом подходе точка сброса груза рассчитывается с учетом фактических параметров полета транспортного беспилотного летательного аппарата: направления захода, высоты и скорости сброса, направления и скорости среднего ветра, баллистических характеристик груза.

Ключевые слова: парашютное устройство, медленно падающий груз, параметр сброса, точка падения груза, баллистические характеристики груза.

\section{METHODICAL GOING NEAR DECISION OF AIMING TASK FOR UPCAST OF SLOWLY FALLING LOADS FROM TRANSPORT PILOTLESS AIRCRAFTS}

\section{Petrov, A. Kudriavtsev, I. Kashaev}

In the article with the use of ballistics of slowly falling bodies, theory and practice of paradropping transport pilotcontrolled aircrafts the methodical going is examined near the decision of aiming task for the automated upcast of slowly falling loads from perspective transport pilotless aircrafts. Under slowly falling loads a military equipment, live ammunitions, food and other soldiery loads, delivered (thrown down) to the troops by a parachute method, is understood. Aiming essence consists in the leading out of a transport pilotless aircraft in a calculation point, at an upcast which the hit of load going down on a parachute is provided from, in the set point (ground). The decision of aiming task comes true in a lateral and longitudinal relation. The lateral aiming is executed by the conclusion of pilotless aircraft in a weather-side on moving away of the expected sidelay of load. The longitudinal aiming comes true by comparison of current and required distance to the set point of landing of load. At equality of these distances and executed lateral aiming there is uncoupling of load and his further decline on a parachute. In the offered methodical approach the point of upcast of load settles accounts taking into account the actual arguments of flight of a transport pilotless aircraft : direction of stopping, height and speed of upcast, ballistic descriptions of load, direction and speed of middle wind in a layer from an earth surface to the height of upcast. The method of calculation of direction and speed of actual middle wind is offered directly in the set district of delivery of load. Essence of method consists in continuous determination of actual directions and speeds of wind, calculation of their mean values at the set of height a pilotless aircraft from maximum small to the height of upcast of load in the district of the set ground. load.

Keywords: parachute device, slowly falling load, parameter of upcast, point of falling of load, ballistic descriptions of 